\title{
Glucose Syrup of Annealing Modified of Cocoyam (Xanthosoma sagittifolium) Starch
}

\author{
Dedin Finatsiyatull Rosida ${ }^{1, *}$, Ricke Amelia ${ }^{1}$ \\ ${ }^{1}$ Department of Food Technology Universitas Pembangunan Nasional Veteran Jawa Timur,Indonesia,60294 \\ *Corresponding author. Email: dedin.tp@upnjatim.ac.id
}

\begin{abstract}
Glucose syrup is made from the hydrolysis of starch which can be hydrolyzed by acid, enzyme, or a combination of both. The liquefaction process in the production of glucose syrup is controlled by the enzymatic hydrolysis by $\alpha$ amylase. The gelatinized starch is hydrolyzed into simpler molecules to be further hydrolyzed by the glucoamylase into glucose. The more effective liquefaction process can facilitate the saccharification process by the glucoamylase. The starch modified by hydrothermal processes such as annealing is hydrolyzed faster by enzymes. Annealing (ANN) method is a modification of starch suspension that results in a moisture content ranging from $40 \%-60 \%$. This process is carried out at temperatures above the glass transition temperature, but still below the gelatinization temperature. This study aims to determine the characteristics of glucose syrup made from modified starch of (Xanthosoma sagittifolium) through enzymatic hydrolysis using $\alpha$-amylase and glucoamylase. Modification is done by annealing method. Annealing is a process in which starch granules are heated in an excess of water at a temperature slightly below the gelatinization temperature for a relatively long time. The annealing process allowed greater accessibility of both enzymes to the amorphous region. This study used a factorial completely randomized design with two factors. The first factor was the concentration of $\alpha$-amylase $(0.01 \% ; 0.02 \%$; and $0.03 \%)$. The second factor was liquefaction time $(90,120$, and 150 minutes). In conclusion, optimal treatment resulting in glucose syrup was obtained from the combination treatment of $0.03 \% \alpha$-amylase enzyme and liquefaction time of 120 minutes. This characteristics resulted yield of $90.73 \%$, water content $17.43 \%$, ash $0.0815 \%$, reducing sugar $770.48 \%$, dextrose equivalent $83.04 \%$, total dissolved solids 79.3 , clarity value 0.0112 , viscosity $2.94 \mathrm{~Pa} . \mathrm{s}$, sweetness level 4.40 and glucose content $60 \%$.
\end{abstract}

Keywords: glucose syrup, starch, cocoyam, annealing, $\alpha$-amylase

\section{INTRODUCTION}

The high starch content in tubers such as cocoyam tubers (Xanthosoma sagittifolium) can be used as raw material for making glucose syrup. That cocoyam has a high starch content of $77.9 \%$ [1]. Cocoyam production in Indonesia is 17316.88 tons [2]. The amylose content of cocoyam was $37.98 \%$, higher than cassava $(33.84 \%)$ [3] and taro tuber (Colocasia esculenta) of $30.62 \%$ [4].

Sugar syrup made from natural starch resulted in a low yield, reducing sugar and dextrose equivalent (DE) compared to the modified starch. Several factors influence the production of glucose syrup, including temperature, $\mathrm{pH}$, substrate concentration, enzyme concentration and hydrolysis time. [5] The liquefaction process is the core process of enzymatic hydrolysis controlled by $\alpha$-amylase and process gelatinized. The gelatinized starch is hydrolyzed into simpler molecules to be further hydrolyzed by the glucoamylase enzyme into glucose. [6] The enzyme glucoamylase, which is an exoamylase, can work effectively when the substrate has been hydrolyzed by the $\alpha$-amylase enzyme. Therefore, the more effective the liquefaction process, the easier the saccharification process by glucoamylase enzymes will be. The enzymatic hydrolysis of glucose syrup is closely related to the amorphous region of starch. [7] The $\alpha$ amylase enzyme hydrolyzes the amorphous region faster than the crystalline region. The crystalline area consists of the amylopectin fraction and the main component of the amorphous area is amylose. [8] Native starch consists of semi-crystalline regions with low amorphous regions. In general, hydrolysis of natural starch by $\alpha$-amylase enzyme is not very effective because it requires a longer hydrolysis time and produces a low yield. [9]Starch modified by hydrothermal processes such as annealing is hydrolyzed faster by enzymes. Annealing (ANN) is a modification by heating the starch suspension for a 
certain time with a water content ranging from $40 \%$ to $60 \% \mathrm{w} / \mathrm{w}$. This process is carried out at temperatures above the glass transition temperature, but still below the gelatinization temperature. Excess water content and heating in the annealing process can cause swelling of the granules, high starch chain mobility in the crystalline part and melting of the crystalline part, either partially or completely, followed by a process of separating the double helical structure of amorphous and crystalline regions so that the amorphous regions increase [9].

The decrease in crystallinity indicated that the crystalline region of the starch was disturbed by the hydrothermal treatment. [10] That double helix motion during hydrothermal treatment can disturb the crystalline area of starch and change the crystal orientation. This explains the changes that occur in starch crystallinity after hydrothermal treatment. [11] A decrease in the degree of crystallinity is closely related to an increase in amorphous regions and starch digestibility. [12] That the increase in amorphous regions of starch modified by the annealing method had a higher susceptibility to the $\alpha$ amylase enzyme than natural starch.

The annealing modification causes the formation of pores on the surface of the starch granules, so that it can increase the susceptibility to the $\alpha$-amylase enzyme. The formation of pores on the surface of starch granules after annealing modification is caused by swelling which causes cracks on the surface of the starch granules. The presence of a porous structure makes starch more susceptible to enzymatic hydrolysis. Annealing modifications carried out prior to enzymatic starch hydrolysis treatment can expand the porous structure. As a result, it can facilitate the penetration of enzymes into the granules during hydrolysis so that the degree of starch hydrolysis will increase. Enzyme hydrolysis in annealed starch occurs mainly on the surface of the starch granules and penetrates into the granules through pores or gaps that have been expanded by the annealing modification. Although amorphous and crystalline lamellae become more regular in annealed starch, accessibility to amorphous regions by enzymes is facilitated by the presence of pores and smectic structures formed due to the annealing process [13]. Some changes in the character of starch occur in the annealing process, including the interaction of starch chains in the amorphous and crystalline parts, an increase in gelatinization temperature, and an increase in amorphous regions [14]. Therefore, this study aims to determine the effect of $\alpha$ amylase concentration and liquefaction time on the production of glucose syrup from modified cocoyam starch using the annealing method.

\section{MATERIALS AND METHOD}

\subsection{Material}

The material used in this research is Cocoyam (Xanthosoma sagittifolium) tubers, the enzymes used are $\alpha$-amylase (Sigma Aldrich) and glucoamylase (Novozymes). Calcium Chloride, Sodium Hydroxide, Hydrochloric Acid, glucose standard, ethanol 95\%, Iodine, Acetate Acid, Potassium Iodide, Fehling A, Fehling B, DNS (2,3-dinitrosalicylic acid), Buffer Potassium Sodium Tartrate 0,2 M pH 6, Sodium sulfate and Sodium Phosphate (Sigma Aldrich).

\subsection{Method}

This study was arranged using a factorial completely randomized design with two factors, namely the concentration of $\alpha$-amylase enzyme $(0.01 \% ; 0.02 \%$; and $0.03 \%)$ and liquefaction time $(90,120$ and 150 minutes $)$. Data were analyzed by analysis of variance. The difference between the two treatments was tested by Duncan Multiple Range Test .

\subsubsection{Cocoyam starch making}

The making of starch begins with stripping and cutting the tubers. Then the tubers were blended for 2 minutes with the addition of $1: 3 \mathrm{w} / \mathrm{v}$ water. Furthermore, the cocoyam tuber paste is extracted by squeezing and filtering using a filter cloth. This milling and filtering process was repeated four times. Then the starch is left for 24 hours. After the starch precipitate is formed, the filtrate is separated. The starch precipitate was washed with water. The starch precipitate was dried in a cabinet dryer at 45 oC for 6 hours. Dry starch was refined and sifted using an 80 mesh sieve. Then the starch was tested for yield [15], moisture content [16], ash content [17], starch content [15], amylose content [15] and degree of crystallinity (XRD method).

\subsubsection{Modification of cocoyam starch using Annealing method}

Preparation of starch suspension by mixing 100 grams of starch added with $300 \mathrm{ml}$ of distilled water (1:3). Furthermore, the heating process is carried out at a temperature of $55{ }^{\circ} \mathrm{C}$ for 24 hours using a water bath shaker. The starch suspension is drained. The starch precipitate was dried in a cabinet dryer at $60{ }^{\circ} \mathrm{C}$ for 6 hours. The modified dry starch was refined and sifted using an 80 mesh sieve. Modified starch was tested for yield [15], moisture content [16], ash content [17], starch content [15], amylose content [15] and degree of crystallinity. 


\subsubsection{Glucose Syrup Making}

The manufacture of glucose syrup by enzymatic hydrolysis consists of two stages, namely the liquefaction stage using the am-amylase enzyme and the saccharification stage using the glucoamylase enzyme. The modified starch suspension with a concentration of $15 \%(\mathrm{w} / \mathrm{v})$ was heated at $78{ }^{\circ} \mathrm{C}$ until the starch solution thickened. The gelatinized starch was conditioned at $\mathrm{pH}$ 5.4 with the addition of $0.1 \mathrm{~N} \mathrm{HCl}$ and $0.1 \% \mathrm{CaCl}_{2}$ (w/w). The amylase enzyme was tested for its activity using the DNS method [18]. Hydrolysis was carried out by adding the enzyme -amylase at a concentration of $0.01 \% ; 0.02 \%$; $0.03 \%$ and heated at $90 \mathrm{C}$ for $90 ; 120$; and 150 minutes using a water bath shaker. The liquefied starch was conditioned at $\mathrm{pH} 4.5$ by adding $0.1 \mathrm{~N} \mathrm{HCl}$ and decreasing the temperature to $60^{\circ} \mathrm{C}$. The process was followed by hydrolysis by $0.05 \%(\mathrm{w} / \mathrm{w})$ glucoamylase enzymes at $60^{\circ} \mathrm{C}$ for 48 hours using a water bath shaker. The resulting glucose syrup filtrate was separated from the unhydrolyzed starch precipitate using filter paper. The glucose syrup was evaporated using a water bath at $100{ }^{\circ} \mathrm{C}$ for 11 hours. The glucose obtained was tested for yield [15], moisture content [16], ash content [17], dextrose equivalent (DE)[19], reducing sugar using the Nelson-Somogyi Method [15], total dissolved solids [20], viscosity [21] and clarity [22].

The sugar purity was tested using HPLC. The work procedure refers to the literature [23] using HPLC waters 2695 which is equipped with a Refractive index detector (LC-RID) and data handling system was Software OpenLab (LCRID) as well as a shodex column asahipak NH2P-50 4D (4.6 x $150 \mathrm{~mm}$ ), eluent $\mathrm{CH}_{3} \mathrm{CHN} / \mathrm{H}_{2} \mathrm{O}=$ $75 / 25$, flow rate $1.0 \mathrm{~mL} / \mathrm{min}$, column temperature $25^{\circ} \mathrm{C}$, injection volume $10 \mu \mathrm{L}$ and run time 20 minutes.
The yield of unmodified starch was $20 \%$, while the modified starch yield of the annealing method was $19.50 \%$. [24]That the addition of water and heating in the annealing modification will cause the starch to dissolve in water, so that the modified starch has a lower yield than natural starch. The amylose content of modified cocoyam starch was higher than that of unmodified starch. The results of starch testing from cocoyam tubers can be seen in Table 1.

The testing results of the crystallinity of annealing modified starch and unmodified starch using XRD (XRay Diffraction) can be seen in Figure 1. Crystallinity can indicate a change in amorphous regions which is indicated by a decrease in crystallinity.

Based on the chromatogram, it can be seen that in the annealing modified starch chromatogram, there are 3 peaks that are gentler than the unmodified cocoyam starch. The degree of crystallinity of modified cocoyam starch was $24.76 \%$, lower than that of unmodified cocoyam starch, which was $32.42 \%$ (Figure 1). Modified sorghum starch annealing method obtained a crystallinity degree of $23.03 \%$ lower than that of unmodified sorghum starch, which was $36.5 \%$ [32]. That hydrogen bonding disturbances between amorphous and crystalline regions by the treatment The heat during the annealing modification process causes the expansion of the amorphous region. The changes produced by heating starch below $100^{\circ} \mathrm{C}$ with high moisture content cause an increase in the degree of association of starch molecules in the granules. Moisture content is an important factor influencing changes in the amorphous region due to the contact between water and starch because reorientation or rearrangement of molecules in starch granules will cause X-ray diffraction patterns to change[35].

\section{RESULTS AND DISCUSSION}

\subsection{Characteristics of Cocoyam Starch}

Table 1. The results of the cocoyam (Xanthosoma sagittifolium) starch test

\begin{tabular}{lcc}
\hline \multicolumn{1}{c}{ Component } & $\begin{array}{c}\text { Annealing modified cocoyam starch P } \\
\text { analysis results }\end{array}$ & analysis results \\
\hline Yield (\%) & 20.00 & 19.50 \\
Water (\%) & $10.15 \pm 0.02$ & $11.89 \pm 0.08$ \\
Ash (\%) & $0.19 \pm 0.002$ & $0.18 \pm 0.003$ \\
Starch (\%) & $87.48 \pm 0.06$ & $87.17 \pm 0.21$ \\
Amylose (\%) & $29.56 \pm 0.06$ & $34.14 \pm 0.18$ \\
Amylopectin (\%) & $70.44 \pm 15.33$ & $65.86 \pm 0.18$ \\
Degree of crystallinity (\%) & 32.42 & 24.76
\end{tabular}



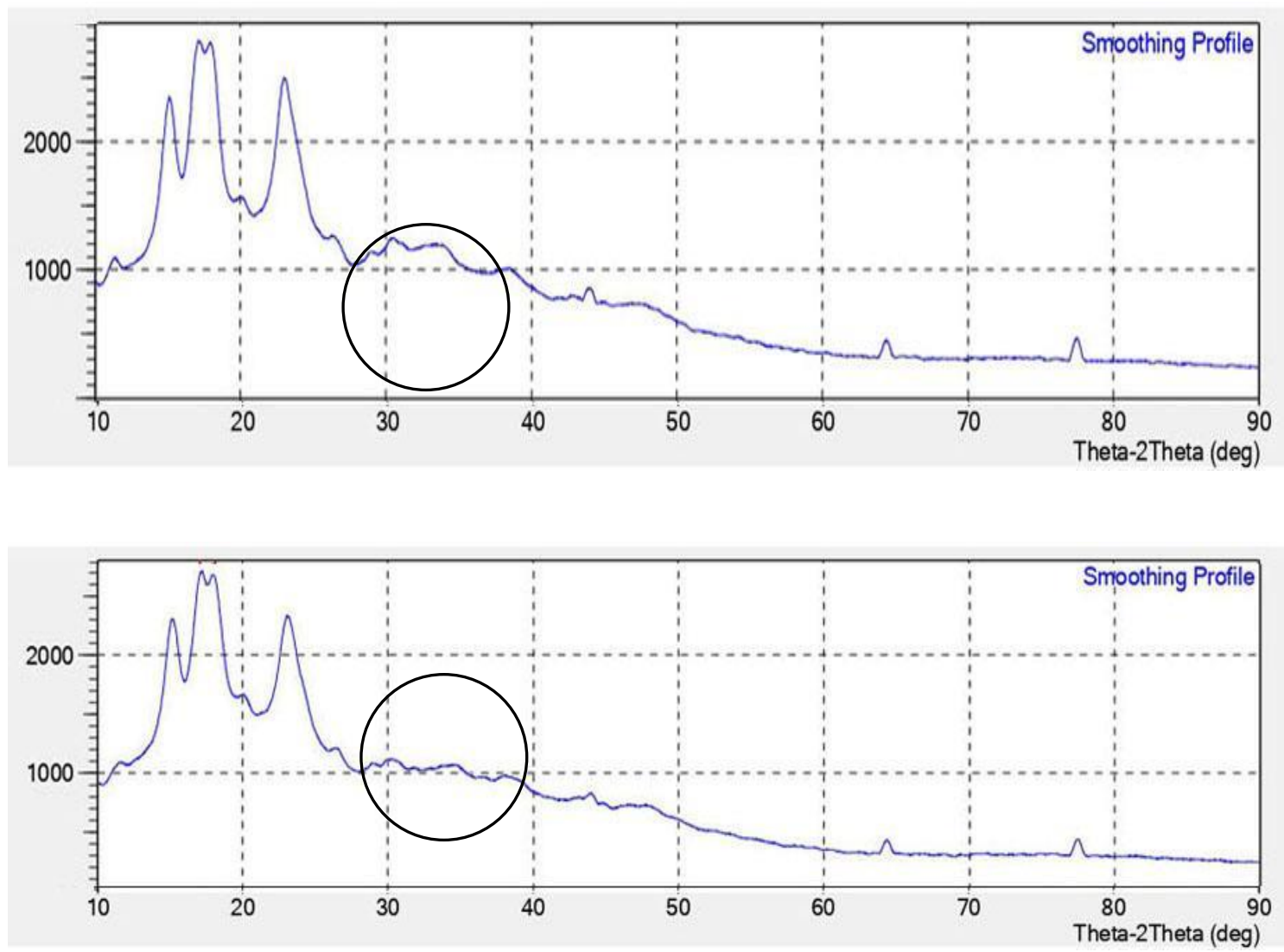

Figure 1. Crystallinity chromatogram results using XRD method: (a) unmodified starch, (b) modified starch annealing

The association between amylose and amylopectin chains in crystal lamellae has a very weak interaction strength, because it involves the interaction of long amylose chains with short amylopectin outer chains. This weak interaction will be disrupted during the reorganization of the starch chain during the annealing process caused by the presence of excessive heat and water conditions, resulting in the cutting of amylopectin long chains located on the outer edge of the amylopectin starch granules into amylose helices and penetration of amylose into the amorphous region. The annealing process causes a decrease in peak intensity and relative crystallinity of starch, so that the relative crystallinity of modified starch using the annealing method is low [36].

Starch modification by the annealing method can increase the amorphous area as indicated by the results of $\mathrm{x}$-ray diffraction (XRD) with wider peaks than the original starch. The wider the peaks produced resulted the larger the amorphous area[33].

The decrease in crystalline area causes starch granules to swell more easily during the gelatinization process. This is in accordance [37] that the double helix and crystalline structure of starch were damaged during the gelatinization process. However, the large crystalline area causes swelling of the starch granules to be restrained by the crystalline structure which is difficult to break. [38] The amorphous region is the part that can expand in the starch gelatinization process. Water absorbed in the amorphous region causes starch granules to lose their crystalline structure stability. The increase in the amorphous region will cause the $\alpha$-amylase enzyme to more easily hydrolyze starch [39].

\subsection{Physical Characteristics of Glucose Syrup}

The yield of glucose syrup is in the range of $84.74 \%$ $-90.73 \%$. This yield research was quite large because the starch was modified using the annealing method. Modification of starch using annealing can increase amylose content and amorphous area which causes starch to be more easily hydrolyzed by the $\alpha$-amylase enzyme so that the yield of the resulting product was higher. [12]That an increase in the amorphous region of starch analyzed by X-ray caused starch modified by the annealing method to have a higher susceptibility to the $\alpha$ amylase enzyme than natural starch.

The addition of $0.03 \%$ enzyme concentration with 120 minutes of liquefaction time resulted in higher yields compared to 150 minutes of liquefaction time with the same $\alpha$-amylase enzyme concentration (Table 2). This is presumably because at the same substrate concentration and enzyme concentration, if the liquefaction time is 
increased, the glucose produced does not increase because the active site of the enzyme is full of substrate. The hydrolysis of annealed modified starch at 120 minutes of liquefaction has intensified so that the $-1,4$ glycosidic bonds in starch have been hydrolyzed by $\alpha$ amylase maximally. The addition of the enzyme concentration will increase the reaction rate. However, the increase in reaction speed will decrease for each increase in enzyme concentration when the amount of substrate is met at a certain concentration.

The water content of glucose syrup ranged from $17.06 \%$ - $19.72 \%$ (Table 2). With $0.03 \% \quad \alpha$-amylase enzyme concentration and 150 minutes of liquefaction time, the lowest water content was $17.06 \%$. The decrease in the water content of glucose syrup along with the increase in enzyme concentration and duration of liquefaction is suspected to be hydrolysis using enzymes requiring water. The use of more enzymes and longer hydrolysis time resulted in less glucose syrup water. The longer the hydrolysis temperature and time, the more water in the sample will evaporate. The increasing concentration of $\alpha$-amylase enzymes will cause the water content of glucose syrup to decrease because more hydroxyl groups are needed during the hydrolysis process. Water will donate its group to complete the monosaccharide group formed from the starch hydrolysis process so that the more starch hydrolyzed by the $\alpha$ amylase enzyme, the lower the water content of glucose syrup. [40]Reported that there was an increase in the hydrolysis of cassava starch along with the addition of enzyme concentration which caused the water content of glucose syrup to decrease.

The ash content of glucose syrup is in the range of $0.157 \%-0.178 \%$. The ash content of glucose syrup can come from the starch used or the $\mathrm{pH}$ adjustment during the hydrolysis or purification process. The total dissolved solids of glucose syrup ranged from 70.5 0Brix -79.25 0Brix. The results [41] showed that the total dissolved solids of glucose syrup from cassava starch were almost the same, ranging from 70 to $78^{\circ}$ brix. The addition of increasing enzyme concentration and longer liquefaction caused the brix grade of modified starch glucose syrup to be produced higher. This can happen because the increase in the degree of brix is closely related to the level of reducing sugar produced. The higher the reducing sugar content, the greater the total dissolved solids in the product. Components measured as total dissolved solids can be organic acids, sucrose, reducing sugars, salts and proteins [42]

The gradual increase in the degree of total dissolved solids indicates that $\alpha$-amylase can convert starch rapidly due to high enzyme activity. The increase in total sugar concentration indicated by total dissolved solids is the same as the increase in reducing sugar concentration [43].

Table 2. The characteristic of glucose syrup from cocoyam modification starch

\begin{tabular}{|c|c|c|c|c|c|c|}
\hline \multicolumn{2}{|c|}{ Treatment } & \multirow[b]{2}{*}{ yield (\%) } & \multirow[b]{2}{*}{ Water(\%) } & \multirow[b]{2}{*}{$\begin{array}{l}\text { Total } \\
\left.\text { solid( }{ }^{\circ} \text { brix }\right)\end{array}$} & \multirow[b]{2}{*}{$\begin{array}{l}\text { Viscosity } \\
\text { (Pa.s) }\end{array}$} & \multirow[b]{2}{*}{ clarity } \\
\hline $\begin{array}{c}\alpha \text {-amilase } \\
(\%)\end{array}$ & $\begin{array}{l}\text { Time } \\
\text { liquefaction } \\
\text { (minuts) }\end{array}$ & & & & & \\
\hline & 90 & $84.74^{a} \pm 0.10$ & $19.72^{\mathrm{g}} \pm 0.01$ & $70.50^{a} \pm 0.71$ & $2.34^{\mathrm{a}} \pm 0.008$ & $7.04^{\mathrm{f}} \pm 0.0007$ \\
\hline \multirow[t]{3}{*}{0.01} & 120 & $86.43^{c} \pm 0.03$ & $19.67^{\mathrm{g}} \pm 0.22$ & $73.75^{c} \pm 0.35$ & $2.51^{c}+0.003$ & $7.35^{\mathrm{e}} \pm 0.0014$ \\
\hline & 150 & $85.65^{b} \pm 0.18$ & $19.49^{\mathrm{f}} \pm 0.04$ & $72.75^{b} \pm 0.35$ & $2.50^{\mathrm{b}} \pm 0.019$ & $7.69^{d} \pm 0.0021$ \\
\hline & 90 & $87.62^{\mathrm{d}} \pm 0.06$ & $19.04^{\mathrm{e}} \pm 0.32$ & $74.25^{\mathrm{c}} \pm 0.35$ & $2.59^{d} \pm 0.016$ & $8.00^{c} \pm 0.0014$ \\
\hline \multirow[t]{2}{*}{0.02} & 120 & $88.48^{\mathrm{f}} \pm 0.24$ & $18.62^{\mathrm{d}} \pm 0.02$ & $77.00^{\mathrm{e}} \pm 0.00$ & $2.73^{\mathrm{e}} \pm 0.013$ & $8.13^{\mathrm{c}} \pm 0.0007$ \\
\hline & 150 & $87.81^{\mathrm{e}} \pm 0.24$ & $18.13^{\mathrm{c}} \pm 0.13$ & $76.25^{\mathrm{d}} \pm 0.35$ & $2.71^{\mathrm{e}} \pm 0.008$ & $8.47^{\mathrm{c}} \pm 0.0014$ \\
\hline \multirow[t]{3}{*}{0.03} & 90 & $89.43^{\mathrm{g}} \pm 0.01$ & $18.03^{b} \pm 0.13$ & $78.25^{\mathrm{f}} \pm 0.35$ & $2.83^{\mathrm{e}} \pm 0.003$ & $8.70^{c} \pm 0.0014$ \\
\hline & 120 & $90.73^{h} \pm 0.08$ & $17.43^{b} \pm 0.15$ & $79.25^{\mathrm{g}} \pm 0.35$ & $2.94^{\mathrm{e}} \pm 0.011$ & $8.93^{\mathrm{b}} \pm 0.0007$ \\
\hline & 150 & $90.04^{\mathrm{h}} \pm 0.17$ & $17.06^{a} \pm 0.06$ & $78.75^{\mathrm{g}} \pm 0.35$ & $2.90^{\mathrm{e}} \pm 0.011$ & $9.26^{\mathrm{a}} \pm 0.0014$ \\
\hline
\end{tabular}

The increasing concentration of enzymes and the liquefaction time is causing the value of clarity and reducing sugar of glucose syrup produce higher and less non-sugar components. The clarity of glucose syrup is influenced by the content of non-sugar components, such as mineral metals, oligosaccharides and other organic 
materials. The more non-sugar components in the syrup, the lower the transmission value or the higher the absorbance value. Clarity and color quality in starch hydrolyzate are influenced by the content of ISSP (Insoluble Starch Particles) in starch. ISSP is starch particles composed mostly of amylose joined together to form a straight chain (linear), the more starch is hydrolyzed to glucose causing the clarity of glucose syrup to increase.

The viscosity of glucose syrup ranges from $2.34 \mathrm{~Pa} . \mathrm{s}$ - 2.83 Pa.s. The addition of alpha amylase enzymes can increase the viscosity of glucose syrup due to the increase in total solids causing an increase in the viscosity of glucose syrup. The longer the hydrolysis time, the more dissolved solids in the liquid sugar are produced so that the more interactions between the molecules of the solids are formed.

\subsection{Reducing Sugar Level}

The reducing sugar content of glucose syrup ranged from $68.64 \%-77.48 \%$ (Figure 2). The treatment of $0.03 \% \quad \alpha$-amylase concentration and 120 minutes liquefaction time obtained the highest reducing sugar content of $77.48 \%$. The reducing sugar content of glucose syrup from modified cocoyam starch was higher. [40] that the starch modification process using the annealing method can increase the amylose content and the area of the amorphous region which causes starch to be more easily hydrolyzed by the $\alpha$-amylase enzyme so that the yield and the reduced sugar content of the resulting product are higher. [44]Starch modified by the hydrothermal process was hydrolyzed more quickly by enzymes and caused the starch granules to swell with water absorption and the crystal structure was disturbed by increasing the amorphous region.
Alpha-amylase is an endoenzyme that cuts the bonds from the middle or inside the 1,4-glycosidic and 1,6glycosidic bonds, the more alpha amylase enzymes are added, the more non-reducing ends are formed so that the glucoamylase enzyme can hydrolyze more[45]. The relationship between the treatment of -amylase enzyme concentration and duration of liquefaction on the reducing sugar content of glucose syrup can be seen in Figure 2 .

In the treatment of $0.03 \% \quad \alpha$-amylase enzyme concentration and 120 minutes of liquefaction time, the highest reducing sugar content was found at $77.48 \%$. Reducing sugar levels will increase along with the addition of the concentration of the $\alpha$-amylase enzyme. However, at the same substrate concentration and enzyme concentration, if the liquefaction time was increased, the reduced sugar content obtained did not increase because the active site of the enzyme was full of substrate. The addition of the enzyme concentration will increase the reaction rate. The increase in reaction speed is indicated by the increasing number of products formed and the amount of substrate that continues to decrease. [41]The increase in yield, the value of DE and reducing sugar will reach a certain limit point, after that point is exceeded there will be no change in yield, the value of DE and reducing sugar will be higher even though the liquefaction period is extended. When the active site of the enzyme is saturated with the substrate, no more substrate can be attached to the active site of the enzyme. This happens because many substrates have been hydrolyzed into reducing sugars, so the addition of hydrolysis time will not increase the reducing sugar content.

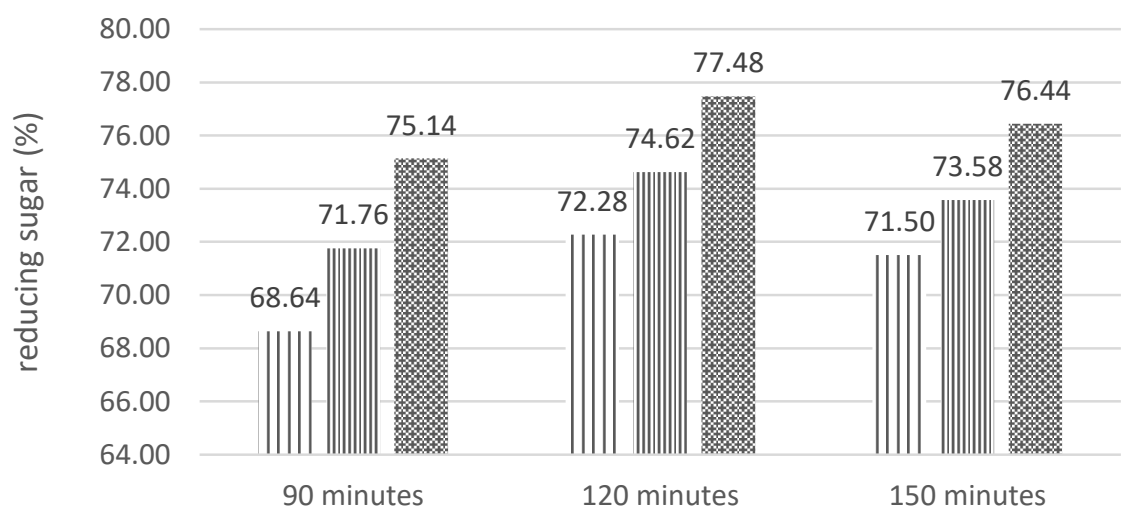

II $\alpha$-amylase concentration $0,01 \%$

IIII $\alpha$-amylase concentration $0,02 \%$

$\alpha$-amylase concentration $0,03 \%$

Figure 2. Relationship of $\alpha$-amylase concentration and liquefaction time on reducing sugar content of glucose syrup 


\subsection{Dextrose Equivalent (DE)}

The Dextrose Equivalent (DE) value of glucose syrup ranged from $72.84 \%-83.04 \%$ (Figure 3). The more addition of $\alpha$-amylase enzyme, the more starch is hydrolyzed into simpler sugars. The $\alpha$-amylase enzyme cleaves the starch randomly at the glycosidic linkage which is then further hydrolyzed into maltose and glucose. [46] That the $\alpha$-amylase enzyme can hydrolyze 1,4 glycosidic bonds in starch polymers internally. The mechanism of action of $\alpha$-amylase is divided into two stages, namely the degradation of amylose and the formation of glucose and maltose. The first step is the degradation of amylose into maltose and maltotriose which occur randomly. The second stage is the formation of glucose and maltose as products and is not random. Both are the action of the $\alpha$-amylase enzyme on the amylose molecule. In the amylopectin molecule, the action of $\alpha$-amylase will produce glucose, maltose and a series of -limit dextrins, as well as oligosaccharides consisting of four or more glucose containing -1,6glycosidic bonds.

These results are better than [47] the making of glucose syrup from cassava starch which produces a Dextrose Equivalent (DE) value of $44.3 \%$. The DE value increased with increasing sugar content. The relationship between the treatment of $\alpha$-amylase enzyme concentration and liquefaction time on the amount of Dextrose Equivalent (DE) glucose syrup can be seen in Figure 3.

Figure 3. shows the treatment with $0.03 \% \alpha$-amylase enzyme concentration and 120 minutes of liquefaction time, the highest Dextrose Equivalent (DE) level is 83.04\% (Figure 3). The glucoamylase enzyme which is an exo amylase can work effectively when the substrate has been hydrolyzed by the $\alpha$-amylase enzyme.
Therefore, the more effective the liquefaction process, the easier the saccharification process by glucoamylase enzymes will be. The Michaelis-Menten model explains that at a certain substrate concentration, increasing the enzyme concentration will increase the reaction rate until finally saturation occurs where the reaction rate does not increase at a certain time.

The DE value of glucose syrup from starch modified using annealing was greater than that using unmodified starch. This can happen because the starch modification process using the annealing method can increase the amylose content and amorphous area, which causes starch to be more easily hydrolyzed by the $\alpha$-amylase enzyme so that the resulting DE value is higher. [48] Amylose and amylopectin were hydrolyzed simultaneously in the amorphous fraction (amylose and intercrystalline regions of amylopectin) of starch granules. The amorphous region can be easily hydrolyzed by the $\alpha$-amylase enzyme.

The value of Dextrose Equivalent (DE) in glucose syrup from waxy corn starch modified using annealing was $67.6 \%$ higher than native starch waxy corn, which was $66.7 \%$. An increase in the value of Dextrose Equivalent (DE) also occurred in glucose syrup from common corn starch modified using annealing by $52.6 \%$, higher than native starch common corn, which was $48.7 \%$ [49].

Modification of annealing can result in the formation of pores in the starch which makes it easier for enzymes to hydrolyze starch. [13]That annealing modification causes the formation of pores on the surface of starch granules, thereby increasing susceptibility to $\alpha$-amylase enzymes. The formation of pores on the surface of starch granules after annealing modification is caused by swelling which causes cracks on the surface of the starch granules. The presence of a porous structure in starch makes starch more susceptible to enzymatic hydrolysis.

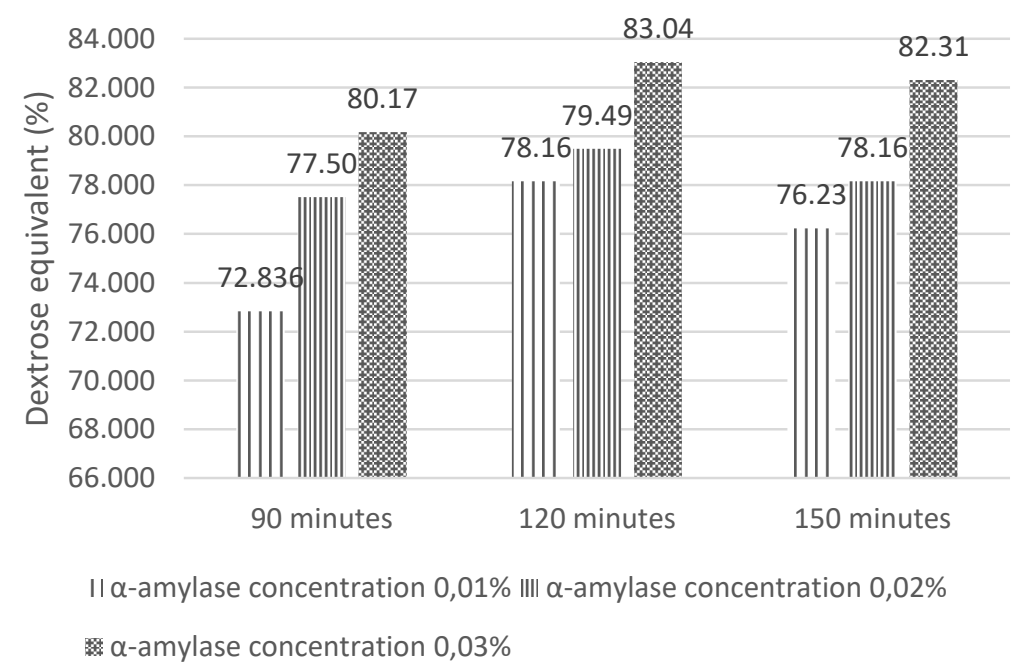

Figure 3. The relationship of $\alpha$-amylase concentration and liquefaction time on the dextrose equivalent (DE) of glucose syrup 


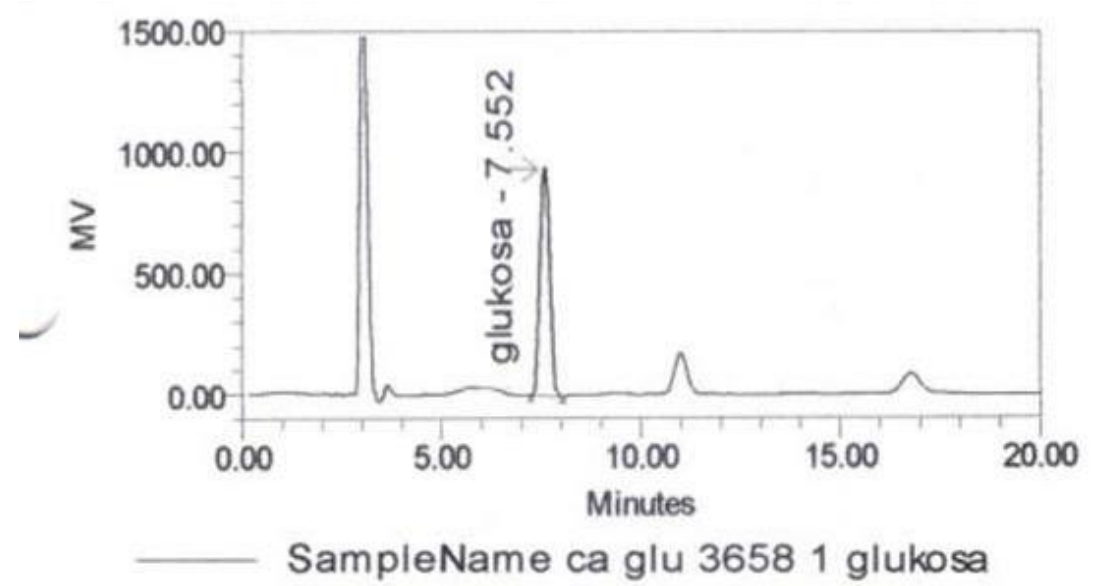

Figure 4. Chromatogram of glucose syrup from annealing modified cocoyam starch

To determine the purity of glucose syrup in treatment of $\alpha$-amylase enzyme concentration of $0.03 \%$ and liquefaction time of 120 minutes were carried out using high performance liquid chromatography (HPLC) in Figure 4. The glucose standard used was 5 different concentrations:

Table 3. The glucose analysis by using HPLC

\begin{tabular}{ll}
\hline $\begin{array}{l}\text { Volume of glucose } \\
\text { standard }\end{array}$ & area of the curve \\
\hline $0.1 \mathrm{ml}$ & 757295 \\
$0.2 \mathrm{ml}$ & $1647336 ;$ \\
$0.5 \mathrm{ml}$ & $3912445 ;$ \\
$1.0 \mathrm{ml}$ & 8059445 \\
$2 \mathrm{ml}$ & 18342587
\end{tabular}

Then from the area of the chromatogram curve, the regression equation $\mathrm{y}=11733786 \mathrm{x}-27341.4$ was obtained. The glucose chromatogram curve was formed with an average area of 14445415 so that it was known that the glucose purity of the annealed modified starch glucose syrup was $60.70 \%$ (Figure 4 ).

\section{CONCLUSION}

The degree of crystallinity of modified cocoyam starch was $24.76 \%$, lower than that of unmodified cocoyam starch, which was $32.42 \%$. Disruption of hydrogen bonds between the amorphous and crystalline regions by heat treatment during the annealing modification process causes expansion of the amorphous regions. The increase in the amorphous region will cause the $\alpha$-amylase enzyme to more easily hydrolyze starch so that it can produce glucose syrup from the aggregated starch more optimally.

This study obtained the optimal result of glucose syrup from annealing modified cocoyam starch with the treatment of $\alpha$-amylase enzyme concentration of $0.03 \%$ and liquefaction time of 120 minutes. This glucose syrup had a yield of $90.73 \%$, water content $17.43 \%$, ash $0.0815 \%$, reducing sugar $77.48 \%$, dextrose equivalent 83.04 , total dissolved solids 79.3 , clarity value 0.0112 , viscosity $2.94 \mathrm{~Pa} . \mathrm{s}$, and glucose purity $60.70 \%$.

\section{ACKNOWLEDGMENTS}

Thank you to the my institution Universitas Pembangunan Nasional Veteran Jawa Timur Indonesia who has funded applied research

\section{REFERENCES}

[1] Rafika, T., Nunung N., dan Laili H. 2012. Sifat organoleptik subtitusi tepung kimpul dalam pembuatan cake. J.Teknologi dan Kejuruan. 35(2)

[2] BPS. 2017. Statistik perdagangan luar negeri impor/imports. CV. Petratama Persada : Jakarta

[3] Polnaya, F.J. Rachel B., Gelora H. Augustyn, dan Helen C.D.T. 2015. Karakteristik sifat-sifat fisikokimia pati ubi jalar, ubi kayu, keladi dan sagu. Agrinimal. 5(1)

[4] Perez, A., Forrest S. Schultzb, and Emperatri'z Pacheco de Delahaye. 2005. Characterization of some properties of starches isolated from Xanthosoma sagittifolium (tannia) and Colocassia esculenta (taro). Carbohydrate Polymers Journal (60)2: 139-145

[5] Wahyuningsih, S. 2019. Pengaruh Konsentrasi Enzim $\alpha$-Amilase pada Hidrolisis Pati Labu Jepang 
(Kabocha). Chemical Engineering Research Article. 2(1)

[6] Yunianta., Tri S., Apriliastuti, T.E., dan Siti N.W. 2010. Hidrolisis secara sinergis pati garut (Marantha arundinaceae 1.) oleh enzim $\alpha$-amilase, glukoamilase, dan pullulanase untuk produksi sirup glukosa. Jurnal Teknologi Pertanian. 11(2)

[7] Jane, J. 2006. Current understanding on starch granule structure. Journal Applied Glycoscience. 5(3)

[8] Sarikaya E., Takahiko H., Motoyasu A., and Bunzo M. 2000. Comparison of degradation abilities of $\alpha$ and $\beta$-amylase on starch granules. Process Biochemistry. 3(5)

[9] Jayakody, L. and Hoover R.. 2008. Effect of annealing on the molecular structure and physicochemical properties of starches from different botanical origins-A review. Carbohydrate Polymers. 7(4)

[10] Gunarate, A. and Hoover R.. 2002. Effect of heatmoisture treatment on the structure and physicochemical properties of tuber and root starches. Carbohydrate Polymer. 49(4)

[11] Farida, D.S. 2011 Perubahan karakteristik pati garut (Marantha arudinacaeae L.) dalam pengembangan pati resisten tipe III. Disertasi. Bogor Fakultas Pertanian Institut Pertanian Bogor.

[12] Serrano, P.O. and Franco C.M.L. 2005. Modificação Hidrotérmica (annealing) e Hidrólise Enzimática do Amido de Mandioca. Brazilian Journal of Food and Technology. 8. 220-232.

[13] Sharriffa, Y.N. Uthumpon U., Karim A.A., and Zaibunnisa A.H. 2017. Hydrolysis of native and annealed tapioca and sweet potato starches at sub gelatinization temperature using a mixture of amylolytic enzymes. International Food Research Journal. 24(5).

[14] Chung, H.J., Liu Q., and Hoover R. 2008. Impact of annealing and heat-moisture treatment on rapidly digestible, slowly digestible and resistant starch levels in native and gelatinized corn, pea and lentil starches. Carbohydrate Polymers. 7(5)

[15] [AOAC]. 2005. Official method of analysis of the association of official analytical of chemists. Arlington, Virginia, USA: Association of Official Analytical Chemists, Inc.

[16] [AOAC] Association of Official Analytical Chemistry. 2012. Official Method of Analysis 923.03, Chapter 32.1.05. Gaithersburg (US): AOAC.
[17] [AOAC] Association of Official Analytical Chemistry. 2012. Official Method of Analysis 925.10, Chapter 32.1.03. Gaithersburg (US): AOAC.

[18] Mayasari. 2016. Pemurnian enzim amilase kasar dari ekstrak bakteri amilolotik endogenous bekatul secara parsial menggunakan amoniun sulfat. tesis. Jurusan Kimia. Fakultas Sains dan Teknologi. Universitas Islam Negeri Maluna Malik Ibrahim Malang

[19] Shi Y.C., L.E James, R. Jeffcoat, and J.J. Kasica. 2000. High Solids Single Phase Process for Preparing Enzyme-Converted Starches. National Starch and Chemical Investment Holding Corporation. Wilmington.

[20] Bayu, M., Rizqiati, H. dan Nurwantoro. 2017. Analisis Total Padatan Terlarut, Keasaman, Kadar Lemak dan Tingkat Viskositas pada Kefir Optima dengan Lama Fermentasi yang Berbeda. Jurnal Teknologi Pangan Vol.1, No.2 : 33-38.

[21] Puteri, M. 2018. Substitusi Tepung Bekatul Beras Merah Terhadap Kadar Protein dan Kekentalan pada Es Krim. tesis. Fakultas Ilmu Kesehatan. Universitas Muhammadiyah Surakarta.

[22] Triyono, Agus. 2008. Karakteristik Gula Glukosa dari Hasil Hidrolisis Pati Ubi Jalar (Ipomoea batatas L.) dalam Upaya Pemanfaatan Pati Umbi-Umbian. Prosiding Seminar Nasional Teknoin Bidang Teknik Kimia dan Tekstil. LIPI Subang.

[23] Alghamdi, B.A., Elham S.A., Muneerah S.B.S, Ghufran M.R., Norah TA., Mohammed N.B., Nawal M.H., Mohemmed Z.A., and Mohd S. 2020. Analysis of sugar composition and pesticides using HPLC and GC-MS techniques in honey samples collected from Arab Saudi markets. Saudi Journal of Biological Science. 27(12): 3720-3726.

[24] Salim, A.R., Putri, dan Widya D.R. 2015. Pengaruh suhu dan lama annealing terhadap sifat fisik-kimia tepung ubi jalar putih varietas manohara. Jurnal pangan dan agroindustri. 3(2)

[25] Leyva, J.D.H, Luis A.B.P., Hernani Y.M., Mario E.R.G., and Andres A.C. 2017. Characterization of the flour and starch of aroid cultivars grown in Mexico. Starch/Stärke. 6(9)

[26] Gudjonsdottir, M., Boakye, A. A., Wireko-Manu, F. D., Chronakis, I., \& Oduro, I. (2016). Characterization of red and white cocoyam roots, flours and starches during heating by low field NMR. In G. Guthausen \& J. van Duynhoven (Eds.), Proceedings of the XIII international conference on 
the applications of magnetic resonance in food science (pp. 49-53).

[27] Falade, K.O and Chidinma A.O. 2013. Physicochemical properties of five cocoyam (Colocasia esculenta and Xanthosoma sagittifolium) starches. Food Hydrocolloids. 30, 173-181

[28] Andrade, L. A., Natália A.B., and Joelma P. 2017. Extraction and properties of starches from the nontraditional vegetables Yam and Taro. Polímeros: Ciência e Tecnologia. 27(2)

[29] Adebowale, K.O. and Lawal O.S. 2002. Effect of annealing and heat moisture conditioning on the physicochemical characteristic of Bambara Groundnut (Voandzeia subterranea) starch. International center of theoretical physics. 46:311316

[30] Akubor, P.I. and Theresa I. 2019. Effect of pre gelatinization and annealing on the chemical composition, functional and pasting properties of starch prepared from unripe banana fruits. South Asian J. Food Technol. Environ.5(1): 807-816

[31] Mweta, D.E., Maryke T.L., Susanna B., Jannie S., and John D.K.S. 2011. Effect of annealing, acid hydrolysis and acetylation on the physicochemical and thermal properties of Malawian cocoyam starch. Trends in Carbohydrate Research. 3(2)

[32] Aviara, N.A., Igbeka J.C., and Nwokocha. L.M.2010. Physicochemical properties of sorghum (sorghum bicolor 1. moench) starch as affected by drying temperature Agricultural Engineering International: the CIGR Ejournal. Manuscript. 10(1)

[33] Song, H.Y., Suk Y.L., Seung J.C., Kyung M.K., Jin S.K., Gui J.H., and Tae W.M. 2013. Digestibility and physicochemical properties of granular sweet potato starch as affected by annealing. Food Sci. Biotechnol. 23(1)

[34] Wang, S., Jinrong W., Shaokang W., and Shuo W. 2017. Annealing Improves paste viscosity and stability of starch. Food Hydrocolloids 62

[35] Samarakoon, E.R.J., Wadugeb R., Liub Q., Shahidia F., and Banoub J.H. 2020. Impact of annealing on the hierarchical structure and physicochemical properties of waxy starches of different botanical origins. Food Chemistry. 3(3)

[36] Dias, A.R.G., Elessandra R.Z., Franciela S., Luis A.S.C, anda Luiz C.G. 2010. Effect Of annealing on the physicochemical properties and enzymatic susceptibility of rice starches with different amylose contents. Food Chemistry Elsevier.
[37] Baks, T., Marieke E. Bruins, Ariette M. Matser, Anja E.M. Janssen, and Remko M. Boom. 2008. Effect of gelatinization and hydrolysis condition on the selectivity of starch hydrolysis with $\alpha$-amylase from Bacillus licheniformis. Journal of Agriculture Food Chemistry 56(2):488-495

[38] Liu Q. 2005. Understanding starches and their role in foods. Food Carbohydrates: Chemistry, Physical Properties and Applications. Cui SW (editor). RC Taylor \& Francis, Boca Raton FL.

[39] Ratnayake, W.S. and Jackson, D.S. (2006). Gelatinization and solubility of corn starch during heating in excess water: new insights. Journal of Agricultural and Food Chemistry 54: 3712-3716.

[40] Ojewumi, M.E., Opeyemi A.A., Oluwaseun M.A. , Damilola E.B., Ayodeji A.A., Olugbenga O.A., Emmanuel O.O., and Oladele J.O. 2018. Evaluation of glucose syrup produced from cassava hydrolyzed with malted grains (rice, sorghum \& maize). International Journal of Pharmaceutical Sciences and Research. 9(8)

[41] Samarayakane, M.D.W., Aeuma B.G.C.J., De Silva, Warnakulasuriya R.D.F., Katudeni V.T., and Herath M.T.H. 2017. Optimization of liquefaction and saccharification times for laboratory scale production of glucose syrup from cassava starch and scaling up process of optimized condition at pilot scale. Research Journal of Chemical. 7(7)

[42] Wee, L.L., Annuar, M., Ibrahim, S. and Chisti, Y. 2011. Enzyme-mediated production of sugars from sago starch: statistical process optimization. Chemical Engineering Communications. 198(11): 1339-1353.

[43] Permanasari, A.R., Fitria Y., Mira A.T., Dahliana A. , dan Ari W. 2018. Pengaruh konsentrasi substrat dan enzim terhadap produk gula reduksi pada pembuatan gula cair dari tepung sorgum merah secara hidrolisis enzimatis. Prosiding Seminar Nasional Teknik Kimia "Kejuangan”. Politeknik Negeri Bandung.

[44] Butterworth, P.J. Frederick J. W. and Peter R. Ellis. 2011. Human a-amylase and starch digestion: An interesting marriage. Starch Journal. 6(3).

[45] obi'a; Sutrisno, Aji. 2015. Karakteristik sirup glukosa dari tepung ubi ungu (kajian suhu likuifikasi dan konsentrasi á-amilase): Kajian Pustaka. Jurnal Pangan dan Agroindustri Vol. 3 No 4 p.1531-1537.

[46] Budiarti, G.I., Siswo S., dan Kusmiyati. 2016. Studi konversi pati ubi kayu (cassava starch) menjadi glukosa secara enzimatik. Jurnal Chemica. 3(1) 
[47] Lambri, M., Roberta D., Arianna R., and Dante M.C.D. 2014. Process development for maltodextrins and glucose syrup from cassava. Chemical Engineering Transaction. 3(8)

[48] Uthumpon, U. Zaidul I.S.M., and Karim A.A. 2010. Hydrolysis of granular a sub gelatinization temperature using a mixture of amylolytic enzyme. Food and Bioproduct Processing. 8(8)

[49] O'Brien, S., and Wang, Y-jane. 2008. Susceptibility of annealed starches to hydrolysis by amylase and glucoamylase. Carbohydrate Polymers. 7(2) 